\title{
Inheritance of type 2 Crigler-Najjar hyperbilirubinaemia
}

\author{
J. O. HUNTER;, R. P. H. THOMPSON, P. M. DUNN, AND ROGER WILLIAMS \\ From the Medical Research Council Group on the Metabolism and Haemodynamics of Liver Disease, \\ King's College Hospital, London, and Department of Child Health, University of Bristol
}

SUMMARY The families of three patients with Crigler-Najjar hyperbilirubinaemia, type 2, whose plasma bilirubin levels had responded to phenobarbitone treatment, were investigated. All the parents and several relatives had mildly raised bilirubin levels.

It is suggested that this condition may be an example of genetic heterogeneity and that the propositi had inherited two different abnormal genes. The separation of the Gilbert and type 2 Crigler-Najjar syndromes is at present arbitrary.

Patients with unconjugated hyperbilirubinaemia not due to haemolysis or to acquired disease have been divided into three types. Those patients with only mildly raised plasma levels, usually less than 5 $\mathrm{mg}$ per $100 \mathrm{ml}$, are the commonest, and are said to have Gilbert's syndrome. Those with plasma levels greater than $5 \mathrm{mg}$ per $100 \mathrm{ml}$ have been placed in two groups (Arias, Gartner, Cohen, Ben Ezzer, and Levi, 1969). Type 1 patients are rare and were first described by Crigler and Najjar (1952). Bilirubin levels are usually greater than $20 \mathrm{mg}$ per $100 \mathrm{ml}$, kernicterus often occurs in infancy, the bile contains no conjugated bilirubin, and there is no detectable activity of bilirubin glucuronyltransferase in homogenates of hepatic tissue. Type 2 patients are less rare. Their bilirubin levels are usually less than $20 \mathrm{mg}$ per $100 \mathrm{ml}$ but are sometimes higher, kernicterus is believed not to occur, conjugated bilirubin is present in small amount in bile, and some activity of glucuronyl-transferase is detectable.

Another difference between type 1 and 2 patients is their response to phenobarbitone, which has no effect in type 1, whereas it reduces the bilirubin levels of patients of type 2, as it also does in Gilbert's syndrome. Arias et al (1969) have suggested that the type 1 disorder is inherited as an autosomal recessive characteristic and type 2 as a dominant, but the frequencies of raised bilirubin levels and of abnormal menthol glucuronidation in the families of the propositi have varied greatly.

${ }^{1}$ Present address: Addenbrooke's Hospital, Cambridge

Received for publication 17 November 1972.
We report here studies of the bilirubin levels in the families of two further type 2 patients in addition to a family previously reported (Smith, Middleton, and Williams, 1967). We suggest that these patients do not inherit a dominant defect but abnormal genes from both parents.

\section{Methods}

Venous blood samples were taken from non-fasting subjects between 8.0 and 10.0 am. Plasma bilirubin concentrations were determined by a modification of Michaelsson's method (Thompson, 1969), normal levels being less than $0.80 \mathrm{mg}$ per $100 \mathrm{ml}$ for men and 0.65 for women (Thompson, Eddleston, and Williams, 1969a). Standard liver function tests were performed. Free $\mathrm{N}$-acetyl aminophenol and its glucuronide were measured by the method of Brodie and Axelrod (1948) and Schmid and Hammaker (1959). The activity of hepatic bilirubin UDP-glucuronyl-transferase was determined by the method of Van Roy and Heirwegh (1968), slightly modified (Pilcher, Thompson, and Williams, 1972).

\section{Findings}

The families came from different parts of the country, and there was no consanguinity.

D.B.

He was a 21-year-old university student who had been jaundiced since childhood (Smith et al, 1967) with bilirubin levels up to $11.0 \mathrm{mg}$ per $100 \mathrm{ml}$ all 


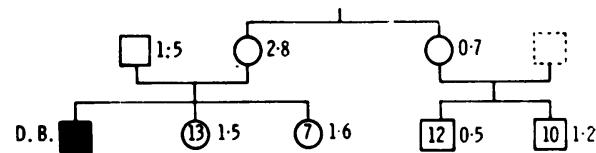

a

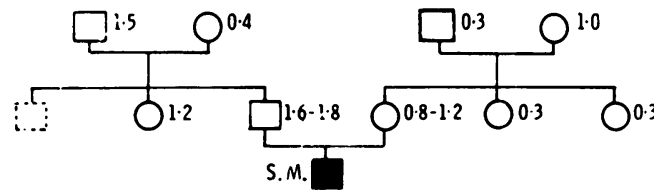

$\begin{aligned} \square & =\text { male } \\ O & =\text { female } \\ \cdots & =\text { not studied }\end{aligned}$

Fig. Family trees of cases D.B. (a) and S.M. (b). Ages within symbols. Bilirubin levels (mg per 100 ml) beside symbols.

unconjugated. Other liver function tests, including the clearance of bromsulphthalein, were normal, as was the histology of a needle biopsy specimen of the liver.

Phenobarbitone and then dicophane ( $\left.p, p^{\prime}-D D T\right)$ therapy reduced the hyperbilirubinaemia (Thompson, Stathers, Pilcher, McLean, Robinson, and Williams, $1969 \mathrm{~b}$ ), the bilirubin levels falling to $1-2 \mathrm{mg}$ per $100 \mathrm{ml}$.

In 1967 his parents, two sibs, maternal aunt, and one of two maternal cousins were found to have mildly raised bilirubin levels of 0.7 to $2.8 \mathrm{mg}$ per $100 \mathrm{ml}$ (Fig. 1).

\section{S.M.}

A male, was the product of a normal pregnancy, and delivery at 39 weeks' gestation. Birth weight was $2.7 \mathrm{~kg}$. He was breast fed, until he was found to have marked unconjugated hyperbilirubinaemia in the first week. There was no hepatic or splenic enlargement, and no kernicterus. Subsequently, at King's College Hospital, at 6-8 months of age, plasma bilirubin levels of 9.5 to $13.8 \mathrm{mg}$ per $100 \mathrm{ml}$ (mean of seven readings: $10.1 \mathrm{mg}$ ) were found, with no direct-reacting pigment; other liver function tests were normal. The histology of a needle biopsy specimen of liver was normal, and no bilirubin glucuronyl-transferase activity was detected in the specimen.

Treatment with phenobarbitone, $1.9 \mathrm{mg} \mathrm{kg}$, failed to lower his bilirubin levels below $6 \cdot 1$ to $8 \cdot 1$ $\mathrm{mg}$ per $100 \mathrm{ml}$ (mean of four readings; $6.6 \mathrm{mg}$ ), but $3.5 \mathrm{mg}$ per $\mathrm{kg}$ then maintained it between 1.5 and $5.0 \mathrm{mg}$ per $100 \mathrm{ml}$ for one year. Mental and motor development have been normal, with the body weight between the 75th and 95th percentiles.

Both parents and several relatives have had mildly raised levels $(0.8-1.8 \mathrm{mg}$ per $100 \mathrm{ml})$ of unconjugated plasma bilirubin (Fig. 1).

H.P.

A female, born after a normal pregnancy, was de- livered at 39 weeks' gestation. Birth weight was 2.5 $\mathrm{kg}$. She was bottle-fed and jaundice was noticed on the third day. At eight days serum bilirubin was 16.5 $\mathrm{mg}$ per $100 \mathrm{ml}$, and $21.5 \mathrm{mg}$ the next day with no direct-reacting pigment. Other liver function tests were normal. The glucuronidation of oral $\mathrm{N}$-acetyl p-aminophenol was markedly impaired compared to a normal infant of the same age. A liver biopsy was not done. Treatment with light therapy and phenobarbitone, starting with $45 \mathrm{mg}$ daily $(16 \mathrm{mg}$ per $\mathrm{kg}$ ), rapidly lowered the bilirubin level, which rose when treatment was stopped. Since then phenobarbitone alone has maintained it between 4 and $8 \mathrm{mg}$ per $100 \mathrm{ml}$ (30 readings) for one year. Development has been normal.

The father had bilirubin levels of 1.7 and $1.5 \mathrm{mg}$ per $100 \mathrm{ml}$ and the mother had one abnormal level of $1.2 \mathrm{mg}$ with three normal values. There are no sibs.

\section{Discussion}

Previous studies of the bilirubin levels in relatives of patients with unconjugated hyperbilirubinaemia have been given widely different results. There may be several reasons for this. Thus methods of measuring bilirubin levels close to the normal range are inaccurate. It is significant that among the previous studies, those in which variations of the JendrassikGrof method have been used have more frequently found abnormal bilirubin levels in relatives (Alwall, Laurell, and Nilsby, 1946; Powell, Hemingway, Billing, and Sherlock, 1967) than have those studies (Arias, 1962; Sleisenger, Kohn, Barniville, Rubin, Ben Ezzer, and Arias, 1967; Arias et al, 1969) in which the Malloy-Evelyn method (Malloy and Evelyn, 1937) has been used. The latter method is especially unreliable at low bilirubin concentrations (Michaëlsson, Nosslin, and Sjölin, 1966). Many reports do not state the time of day when samples were taken in spite of the large fluctuations of bilirubin levels during the day (With, 1968), and 
this may also allow abnormal levels to be missed. The upper limit of normal for bilirubin has frequently been taken to be $1.0 \mathrm{mg}$ per $100 \mathrm{ml}$ or greater, but careful studies have shown a skew distribution of the few values above $0.8 \mathrm{mg}$ per $100 \mathrm{ml}$ in men, and a pronounced sex difference (Powell et al, 1967; Thompson et al, 1969a); again abnormal levels could thus be missed.

Further sources of error are differences in food intake which affect bilirubin levels (With, 1968), and the ingestion of enzyme-inducing drugs, such as sleeping tablets and anticonvulsant drugs, which reduce bilirubin levels (Thompson et al, 1969a). Thus the paternal grandmother of S.M. had a normal bilirubin level but was taking phenylbutazone which is known to induce hepatic microsomal enzymes (Conney, 1967). Bilirubin levels are probably lower in children, so that levels in younger relatives, such as in one of the cousins of D.B., may later become higher. All the parents of the propositi had mildly but definitely abnormal bilirubin levels, the only two siblings of the propositi (both of case D.B.) also had raised levels, and the levels of several other relatives were abnormal. The prevalence of abnormal bilirubin levels in the families of these patients is therefore probably higher than has been reported (Arias et al, 1969).

The inheritance of this condition has also been studied by testing the relatives for the in-vivo glucuronidation of substrates such as menthol, and abnormal results have frequently been found (Szabó and Ébrey, 1963; Sleisenger et al, 1967; Arias et al, 1969). These may, however, be unreliable, for the glucuronidation of bilirubin could be different from that of other substrates. In the Gunn strain of rat, which, like type 1 patients, has a total bilirubin glucuronyl-transferase deficiency, the glucuronidation of some substrates is selectively impaired; this may be so in these patients and their families.

It is possible that our propositi are homozygous for a common abnormal gene for which all patients with mildly raised bilirubin levels are heterozygous. If so, owing to the high frequency (perhaps $1 \%$ ) of abnormal bilirubin levels in the population, the prevalence of type 2 patients should be higher than it is. Alternatively, the wide range of bilirubin levels found in type 2 patients may indicate that there is a range of allelomorphs for each of the genes that control the processes of uptake and conjugation of bilirubin. The enzymes synthesized by these genes need only differ in one amino acid, and therefore in stability or specific activity (Harris, 1970). Combinations of mildly abnormal genes would result in the observed range of phenotypes with abnormal bilirubin levels, so our propositi with bilirubin levels much higher than those of their parents would be heterozygous for each of two different, abnormal genes. Twin studies would be helpful (Wetstone and Honeyman, 1969) in deciding this.

There is a continuous spectrum of abnormality among those patients with non-haemolytic hyperbilirubinaemia who respond to phenobarbitone. Their separation into Crigler-Najjar type 2 and Gilbert's syndrome is therefore arbitrary, especially since the activity of glucuronyl-transferase is probably greatly reduced in the latter also (Black and Billing, 1969). The position is different in patients with severe hyperbilirubinaemia presumed unresponsive to phenobarbitone who have been reported from the United States (Crigler and Najjar, 1952; Childs and Najjar, 1965; Arias et al, 1969), Canada (Huang, Rozdilsky, Gerrard, Goluboff, and Holman, 1970), and Hungary (Szabó, Kovács, and Ébrey, 1962). Their parents, for instance, may not have raised bilirubin levels, and from the reports the condition seems to be recessively inherited. The bilirubin level of $21.5 \mathrm{mg}$ per $100 \mathrm{ml}$ of H.P. does, however, suggest that kernicterus could occur in type 2 patients as well as type 1 , so that the response to phenobarbitone is at present the best test to differentiate them.

We are grateful to Dr John Holton and J. T. Allen for the glucuronidation test. R.P.H.T. was in receipt of a Medical Research Council clinical research fellowship.

\section{References}

Alwall, N., Laurell, C. B., and Nilsby, I. (1946). Studies on heredity in cases of 'non-hemolytic hyperbilirubinemia without direct Van den Bergh reaction' (hereditary, non-hemolytic bilirubinemia). Acta med. scand., 124, 114-125.

Arias, I. M. (1962). Chronic unconjugated hyperbilirubinemia without overt signs of hemolysis in adolescents and adults. J. clin. Invest., 41, 2233-2245.

Arias, I. M., Gartner, L. M., Cohen, M., Ben Ezzer, J., and Levi, A. J. (1969). Chronic nonhemolytic unconjugated hyperbilirubinemia with glucuronyl transferase deficiency. Amer. J. Med., 47, 395-409.

Black, M., and Billing, B. H. (1969). Hepatic bilirubin UDPglucuronyl transferase activity in liver disease and Gilbert's syndrome. New. Engl. J. Med., 280, 1266-1271.

Brodie, B. B., and Axelrod, J. (1948). The estimation of acetanilide and its metabolic products, aniline, $\mathrm{N}$-acetyl p-aminophenol and p-aminophenol (free and total conjugated) in biological fluids and tissues. J. Pharmacol. exp. Ther., 94, 22-38.

Childs, B., and Najjar, V. A. (1956). Familial nonhemolytic jaundice with kernicterus. Pediatrics, 18, 369-377.

Conney, A. H. (1967). Pharmacological implications of microsomal enzyme induction. Pharmacol. Rev., 19, 317-366.

Crigler, J. F., Jr., and Najjar, V. A. (1952). Congenital familial nonhemolytic jaundice with kernicterus. Pediatrics, 10, 169-179.

Harris, H. (1970). Genetical theory and the 'inborn errors of metabolism'. Brit. med. J., 1, 321-327.

Huang, P. W. H., Rozdilsky, B., Gerrard, J. W., Goluboff, N., and Holman, G. H. (1970). Crigler-Najjar syndrome in four of five siblings with postmortem findings in one. Arch. Path., 90, 536-542 
Malloy, H. T., and Evelyn, K. A. (1937). The determination of bilirubin with the photoelectric colorimeter. J. biol.' Chem., 119, 481-490.

Michaëlsson, M., Nosslin, B., and Sjölin, S. (1965). Plasma bilirubin determination in the newborn infant. Pediatrics, 35, 925-931.

Pilcher, C. W. T., Thompson, R. P. H., and Williams, R. (1972). Effect of phenobarbitone on hepatic microsomal enzymes of the male rat. Biochem. Pharmacol., 21, 129-133.

Powell, L. W., Hemingway, E., Billing, B. H., and Sherlock, S. (1967). Idiopathic unconjugated hyperbilirubinemia (Gilbert's syndrome). New Engl. J. Med., 277, 1108-1112.

Schmid, R., and Hammaker, L. (1959). Glucuronide formation in patients with constitutional hepatic dysfunction (Gilbert's disease). New Engl. J. Med., 260, 1310-1314.

Sleisenger, M. H., Kahn, I., Barniville, H., Rubin, W., Ben Ezzer, J., and Arias, I. M. (1967). Nonhemolytic unconjugated hyperbilirubinemia with hepatic glucuronyl transferase deficiency: a genetic study in four generations. Trans. Ass. Amer. Phycns, 80, 259.266.

Smith, P. M., Middleton, J. E., and Williams, R. (1967). Studies on the familial incidence and clinical history of patients with chronic unconjugated hyperbilirubinaemia. Gut, 8, 449-453.
Szabó, L., and Ébrey, P. B. (1963). Studies on the inheritance of CriglerNajjar's syndrome, by the menthol test. Acta paediat. Acad. Sci. hung., 4, 153-158.

Szabó, L., Kovács, Z., and Ébrey, P. B. (1962). Crigler-Najjar's syndrome. Acta paediat. Acad. Sci. hung., 3, 49-70.

Thompson, R. P. H. (1969). Modification of Michaëlsson's method for the measurement of plasma total bilirubin. J. clin. Path., 22, 439-441.

Thompson, R. P. H., Eddleston, A. L. W. F., and Williams, R. (1969). Low plasma-bilirubin in epileptics on phenobarbitone. Lancet, 1, 21-22.

Thompson, R. P. H., Stathers, G. M., Pilcher, C. W. T., McLean, A. E. M., Robinson, J., and Williams, R. (1969). Treatment of unconjugated jaundice with dicophane. Lancet, 2, 4-6.

Van Roy, F. P., and Heirwegh, K. P. M. (1968). Determination of bilirubin glucuronide and assay of glucuronyl transferase with bilirubin as acceptor. Biochem. J., 107, 507-518.

Wetstone, H. J., and Honeyman, M. S. (1969). Definition of normal blood bilirubin. New Engl. J. Med., 278, 564.

With, T. K. (1968). Bile Pigments. Academic Press, New York. 